\title{
FORMULASI SEDIAAN KRIM EKSTRAK BIJI KAKAO (Theobroma cacao) SEBAGAI ANTIBAKTERI Propionibacterium acne
}

\author{
Formulation Of Cream Cocoa Bean (Theobroma Cacao) Exctract \\ As Antibacterial Against Propionibacterium Acne \\ Siti Nurjanah, Nopiyansyah, Ira Dwi Rahmawati \\ Program Studi Farmasi, Universitas Tulang Bawang Lampung \\ e-mail : titieajah05@gmail.com \\ 08117243434
}

\begin{abstract}
Cocoa bean is one part cocoa plant which has many benefit in the health field. Polyphenolic compounds cocoa bean proven to have activity antioxidants and antibacterial. This research purposes to prove that cocoa bean extract (Theobroma cacao) could be formulated become cream preparation and had antibacterial activity against Propionibacterium acne. In this research cocoa bean extract formulated in cream preparation with different extract concentration such as, F1 (3\%), F2 (6\%) and F3 (12\%) with using stearic acid, paraffin liquid, adepslanae, as oil phase, TEA, aquadest as water phase, and methyl paraben as preservative. Then that were evaluated of homogenity, organoleptic, $\mathrm{pH}$, viscosity dispersive power, glutinous power and inhibition power of antibacterial. Result of evaluation of stock had a $\mathrm{pH}$ range of between $6,4-8,1$, the viscosity range from $2324-526$ cps 1 , dispersive power between 5,47-6,95 cm, and the glutinous power between 4,2-5,3 second. Each formula was stable in storage cycling testand temperature $40^{\circ} \mathrm{C} \pm 2^{\circ} \mathrm{C}, 28^{\circ} \mathrm{C} \pm 2^{\circ} \mathrm{C}, 4^{\circ} \mathrm{C} \pm 2^{\circ} \mathrm{C}$ and the three formulas had antibacterial of Propionibacterium acne. The conclusion of this study is cocoa bean extract could be formulated in cream preparations and had a zone of inhibition against bacteria Propionibacterium acne.
\end{abstract}

Keywords: Antibacterial cream, Propionibacterium acne, Theobroma cacao

\begin{abstract}
Abstrak
Biji kakao merupakan salah satu bagian tanaman kakao yang diyakini memiliki banyak manfaat di bidang kesehatan. Senyawa polifenol biji kakao terbukti memiliki aktivitas antioksidan dan antibakteri. Berdasarkan sifat antibakterinya maka ekstrak biji kakao dikembangkan menjadi sediaan krim untuk mengobati jerawat yang disebabkan oleh bakteri Propionibacterium acne. Penelitian ini bertujuan untuk membuktikan bahwa ekstrak biji kakao (Theobroma cacao) dapat di formulasikan menjadi sediaan krim dan memiliki aktivitas antibakteri terhadap Propionibacterium acne. Pada penelitian ini ekstrak biji kakao diformulasikan dalam sediaan krim dengan konsentrasi ekstrak berbeda yaitu $\mathrm{F} 1$ (3\%), F2 $(6 \%)$ dan F3 (12\%) dengan menggunakan asam stearat, paraffin liquidum, adeps lanae sebagai fase minyak dan TEA, aquadest sebagai fase air, dan metil paraben sebagai pengawet. Kemudian diuji sifat fisik sediaan meliputi , homogenitas, pemeriksaan organoleptis (bentuk, bau danwarna), pengukuran $\mathrm{pH}$, viskositas, daya sebar, daya lekat, uji stabilitas dan uji antibakteri. Hasil evaluasi sediaan, ketiga formula memiliki nilai pH berkisar

antara 6,4-8,1, viskositas berkisar antara $2324-5261 \mathrm{cps}$, daya sebar antara 5,47-6,95 cm, dan daya lekat 4,2-5,3 detik.. Setiap formula stabil dalam penyimpanan cycling test serta
\end{abstract}


penyimpanan suhu $40^{\circ} \mathrm{C} \pm 2^{\circ} \mathrm{C}, 28^{\circ} \mathrm{C} \pm 2^{\circ} \mathrm{C}, 4^{\circ} \mathrm{C} \pm 2^{\circ} \mathrm{C}$ dan ketiga formula memiliki sifat antibakteri terhadap Propionibacterium acne dengan luas zona hambat F1 $(7,61 \mathrm{~mm})$, F2 $(8,47)$ dan F3 $(9,92 \mathrm{~mm})$. Kesimpulan dari penelitian ini yaitu ekstrak biji kakao dapat diformulasikan dalam sediaan krim dan memiliki zona hambat terhadap bakteri Propionibacterium acne..

Kata kunci :Krim antibakteri, Propionibacterium acne, Theobroma cacao

\section{PENDAHULUAN}

Indonesia merupakan Negara penghasil kakao terbesar ketiga didunia dengan produksi yang terus tumbuh 3,5 persen setiap tahunnya dan sangat potensial untuk dimanfaatkan. Salah satu potensi pada tanaman kakao yang bisa dimanfaatkan dalam bidang kesehatan ialah pada biji. Senyawa polifenol yang terkandung dalam biji kakao cukup besar meliputi flavonoid sebagai komponen dasar, katekin 33-42 \%, tannin 24-40\%. Senyawapolifenolbijikakaoterbuktimemiliki aktivitasantioksidandan anti bakteri [1]

Bakteri yang umum menginfeksi jerawat adalah Staphylococcus epidermidis, Sthaphylococcus aureus, dan Propioni bacterium acne. P.acne merupakan flora normal dari kelenjar pilosebases kulit manusia, bakteri ini menyebabkan jerawat dengan menghasilkan lipase yang memecah asam lemak bebas dari lipid kulit.Pengobatan yang lazim digunakan adalah dengan menggunakan antibiotik, seperti tetrasiklin, eritromisin, doksisiklindan clindamycin.Selain itu pengobatan lain juga dapat menggunakan benzoil peroksida, asam azelat dan retinoid [2] [3].

Namun obat-obat tersebut memiliki efek samping dalam penggunaannya antara lain iritasi, dan menyebabkan resistensi antibiotik. Untuk mengatasi penggunaan antibiotik dalam pengobatan, dapat digunakan alternative pengobatan bahan alam yang berasal dari ekstrak biji kakao yang dibuat dalam sediaan krim. Krim merupakan suatu sediaan setengah padat berupa emulsi kental mengandung air tidak kurang dari $60 \%$. Emulsi merupakan campuran dari fase air dan fase minyak, sehingga dibutuhkan emulgator untuk membentuk emulsi yang baik yaitu keadaan dimana kedua fase dapat bergabung. Penelitian sebelumnya membuktikan bahwa ekstrak biji kakao dapat menghambat pertumbuhan bakteri P.acne[4] [5]. Sehingga dilakukan penelitian lebih lanjut yang bertujuan untuk membuat sediaan krim dari ekstrak biji kakao yang memiliki antivitas antibakteri

\section{METODE PENELITIAN}

Metode penelitian ini adalah eksperimental laboratorium.

\section{Alat dan Bahan}

Alat yang digunakan adalah alat rotary evaporator, oven (memmert), press hidrolic, kompor gas, timbangan, cawan petri, autoklaf, kawat ose, tabung reaksi, Erlenmeyer (pyrex), gelas ukur (pyrex), mortir, penangas air, batang pengaduk, inkubator (memmert), rak tabung, corong, blue tip, botol gelap, pot krim, mikropipet (socorex), viskometer (haake 550), $\mathrm{pH}$ meter ( martini Mi151).

Bahan yang akan digunakan adalah biji kakao, etanol $70 \%$, n-hexana $\left(\mathrm{C}_{6} \mathrm{H}_{14}\right)$, $P$.acne, media agar NA, media agar NB aquadest $\left(\mathrm{H}_{2} \mathrm{O}\right)$, paraffin liquidum $\left(\mathrm{C}_{14}-\mathrm{C}_{8}\right)$, asam stearat $\left(\mathrm{CH}_{3}\left(\mathrm{CH}_{2}\right){ }_{16} \mathrm{COOH}\right)$, trietanolamin $\left(\mathrm{C}_{6} \mathrm{H}_{15} \mathrm{NO}_{3}\right)$, adeps lanae $\left(\mathrm{C}_{48} \mathrm{H}_{69} \mathrm{NO}_{2}\right)$, metil parabean $\left(\mathrm{C}_{8} \mathrm{H}_{8} \mathrm{O}_{3}\right)$, dan krim vitacid $0,05 \%$ retinoid acid. 


\section{Prosedur}

\section{Determinasi}

Determinasi tanaman kakao dilakukan di Laboratorium Botani Jurusan Biologi Fakultas Matematika dan IImu Pengetahuan Alam Universitas Lampung

\section{Pembuatan Ekstrak Biji Kakao}

Biji kakao basah seberat $4 \mathrm{~kg}$ dicuci bersih lalu dijemur dibawah sinar matahari langsung selama 2 hari, kemudian dioven dengan suhu $60^{\circ} \mathrm{C}$ selama 30 menit untuk memudahkan proses pengepressan. Biji kakao yang sudah kering dipisahkan dengan lemak kakao menggunakan press hidrolic dan menghasilkan bungkil kakao. Setelah itu, bungkil kakao direndam dengan n-hexana selama 24 jam. Larutan yang diperoleh disaring dan dipress menggunakan press hidrolic sehingga diperoleh bungkil kakao kembali. Kemudian bungkil ini di lakukan proses maserasi sampai pelarut berwarna jernih dengan cara direndam dengan etanol $70 \%$ sampai terendam sempurna kemudian larutan dievaporasi menggunakan evaporator dan menghasilkan ekstrak etanol pekat [5].

Tabel 1. Formulasi Sediaan Krim Ekstrak Biji Kakao

\begin{tabular}{l|l|l|l|l}
\hline NamaBahan & F0 & F1 & F2 & F3 \\
\hline $\begin{array}{l}\text { EkstrakBijiKakao } \\
\text { (ml) }\end{array}$ & 0 & 3 & 6 & 12 \\
\hline $\begin{array}{l}\text { Paraffin } \\
\text { Liquidum (ml) }\end{array}$ & 15 & 15 & 15 & 15 \\
\hline AsamStearat (g) & 10 & 10 & 10 & 10 \\
\hline $\begin{array}{l}\text { Trietanolamin } \\
(\mathrm{ml})\end{array}$ & 2 & 2 & 2 & 2 \\
\hline AdepsLanae (g) & 3 & 3 & 3 & 3 \\
\hline MetilParaben (g) & 0,3 & 0,3 & 0,3 & 0,3 \\
\hline Aquadest (ml) & $\begin{array}{l}\mathrm{Ad} \\
100\end{array}$ & $\begin{array}{l}\mathrm{Ad} \\
100 \\
\mathrm{ml}\end{array}$ & $\begin{array}{l}\mathrm{Ad} \\
100\end{array}$ & $\begin{array}{l}\mathrm{Ad} \\
100\end{array}$ \\
\hline
\end{tabular}

\section{Pembuatan Sediaan Krim}

Pembuatan basis krim dilakukan dengan cara fase minyak (paraffin liquidum, asam stearat, adeps lanae) dan fase air (metil paraben, TEA, dan aquadest) masingmasing dimasukkan dalam cawan porselen secara terpisah, dipanaskan diatas penangas hingga meleleh secara bersamaan dan diaduk hingga homogen. Setelah itu 2 fase tersebut dicampurkan sekaligus dalam mortir panas lalu gerus sampai dingin sampai terbentuk masa basis krim yang homogen. Masukkan ekstrak etanol biji kakao ke dalam lumpang, tambahkan basis krim untuk masing-masing formula sedikit demi sedikit kemudian tambahkan metil paraben lalu gerus hingga homogen. Lalu masingmasing formula disimpan dalam wadah krim.

\section{Evaluasi Krim}

\section{a. Uji Homogenitas}

Uji homogenitas ini dilakukan denganmengoleskan sediaan pada objek glass dan diamati homogenitasnya [6].

\section{b. Pengamatan Organoleptis}

Masing-masing sediaan krim diamati bentuk, bau dan warna sediaan.

\section{c. Pengukuran pH}

Pengukuran $\mathrm{pH}$ dilakukan dengan cara menimbang krim sebanyak $10 \mathrm{~g}$ dimasukkan ke dalam beker gelas, tambahkan $10 \mathrm{ml}$ air hangat dengan suhu $27^{\circ} \mathrm{C}$, aduk sampai terbentuk suspensi. Diamkan selama 5 menit, kemudian ukur pHnya. Pengukuran $\mathrm{pH}$ dilakukan dengan cara mencelupkan alat $\mathrm{pH}$ meter ke dalam sediaan krim sampai menunjukkan angka yang konstan setelah beberapa saat [7]

\section{d. Viskositas}

Pengukuran viskositas dilakukan dengan cara sediaan dimasukkan ke dalam wadah 
berupa tabung silinderdan spindle yang sesuai dimasukkan sampai garis batas lalu diputar dengan kecepatan tertentu sampai angka viskometer menunjukan skala yang konstan.

\section{e. Uji Daya Sebar}

Uji daya sebar ini dilakukan dengan cara : sampel salep dengan berat 0,5 gram diletakkan ditengah kaca bulat, tutup dengan kaca lain yang telah ditimbang beratnya, lalu diukur diameter daya sebar krim. Setelah itu, ditambahkan beban 50 gram dan dibiarkan 1 menit, kemudian diukur diameter sebarnya. Penambahan seberat 50 gram selama 1 menit dilakukan secara terus menerus sehingga mendapatkan diameter yang cukup untuk melihat pengaruh beban terhadap perubahan diameter sebar krim [8]

\section{f. Uji Daya Lekat}

Pengujian daya lekat dilakukan dengan cara menimbang krim dengan berat 0,25 gram diletakkan diatas dua gelas objek yang telah ditentukan beratnya kemudian ditekan dengan beban $1 \mathrm{~kg}$ selama 5 menit. Setelah itu, gelas objek dipasang pada alat tes. Alat tes diberi beban 80 gram dan kemudian dicatat waktu pelepasan krim dari gelas objek [8].

\section{g. Metode Cycling Test}

Uji stabilitas ini dilakukan terhadap semua formula sediaan disimpan pada suhu $4^{\circ} \mathrm{C}$ dalam lemari pendingin selama 24 jam lalu pindahkan ke dalam oven yang bersuhu $40^{\circ} \mathrm{C}$ selama 24 jam (satu siklus), kemudian uji dilakukan sebanyak 6 siklus kemudian diamati terjadi adanya pemisahan fase [7]

\section{Uji Stabilitas Krim}

1. Penyimpanan pada suhu tinggi Sampel disimpan pada suhu $40^{\circ} \mathrm{C} \pm 2^{\circ} \mathrm{C}$ selama 4 minggu kemudian dilakukan evaluasi fisik setiap 1 minggu.

2. Penyimpanan pada suhu kamar
Sampel disimpan pada suhu $25^{\circ} \mathrm{C} \pm 2^{\circ} \mathrm{C}$ selama 4 minggu kemudian dilakukan evaluasi fisik setiap 1 minggu.

3. Penyimpanan pada suhu rendah

Sampel disimpan pada suhu $4^{\circ} \mathrm{C} \pm 2^{\circ} \mathrm{C}$ selama 4 minggu kemudian dilakukan evaluasi fisik setiap 1 minggu [6].

\section{Uji Daya Antibakteri}

Uji aktivitas antibakteri krim ekstrak biji kakao ini digunakan dengan metode difusi yaitu metode sumuran.Siapkan cawan petri steril kemudian tuangkan $100 \mu \mathrm{l}$ suspensi bakteri lalu tambahkan media NA, homogenkan kemudian biarkan memadat.Setelah itu buat lubang sumuran menggun akan blue tip. Formula krim dimasukkan dalam masing - masing sumuran tiap cawan petri berisi4 konsentrasi dengan metil paraben,dan kontrol positif diletakkan dalam satu cawan dan 4 konsentrasi tanpa metil paraben dan kontrol positif di cawan lain kemudian diinkubasi selama 24 jam dengan suhu $37^{\circ} \mathrm{C}$, setelah itu diamati serta ukur diameter zona hambat yang terbentuk disekitar lubang sumuran dengan menggunakan jangka sorong.

\section{HASIL DAN PEMBAHASAN}

\section{Sediaan Krim Ekstrak Biji Kakao}

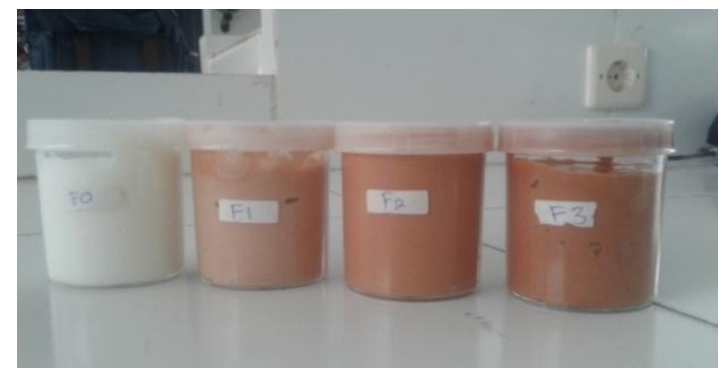

Gambar 1. Sediaan Krim

Keterangan:

$\mathrm{FO}=$ formula blangko

$\mathrm{F} 1$ = krim dengan konsentrasi ekstrak bii kakao 3\%

$\mathrm{F} 2$ = krim dengan konsentrasi ekstrak biji kakao 6\%

F3 = krim dengan konsentrasi ekstrak biji kakao $12 \%$ 
Pada penelitian ini dibuat formulasi dengan variasi konsentrasi ekstrak biji kakao yaitu $3 \%, 6 \%, 12 \%$ dengan basis yang sama.

Tabel 2. Hasil Uji Organoleptis

\begin{tabular}{c|c|c|c}
\hline $\begin{array}{c}\text { For } \\
\text { mula }\end{array}$ & Warna & Bentuk & Aroma \\
\hline F0 & Putih & $\begin{array}{c}\text { Semi } \\
\text { padat }\end{array}$ & Khas adeps \\
\hline F1 & Coklat & $\begin{array}{c}\text { Semi } \\
\text { padat }\end{array}$ & $\begin{array}{c}\text { Kurang berbau } \\
\text { khas ekstrak }\end{array}$ \\
\hline F2 & $\begin{array}{c}\text { Coklat } \\
\text { muda }\end{array}$ & $\begin{array}{c}\text { Semi } \\
\text { padat }\end{array}$ & $\begin{array}{c}\text { Cukupberbau } \\
\text { khas ekstrak }\end{array}$ \\
\hline F3 & $\begin{array}{c}\text { Coklat } \\
\text { tua }\end{array}$ & $\begin{array}{c}\text { Semi } \\
\text { padat }\end{array}$ & Khas ekstrak \\
\hline
\end{tabular}

Dari Tabel 2 di atas formula krim yang memiliki basis yang sama dengan konsentrasi zat aktif yang berbeda, memiliki sifat organoleptis yang berbeda pula. Dengan demikian, organoleptis sediaan dipengaruhi oleh konsentrasi ekstrak yang digunakan.Semakin tinggi konsentrasi ekstrak yang digunakan warna yang dihasilkan semakin coklat serta memiliki aroma yang semakin khas. Hal ini terbukti pada F3 (12\%) memiliki warna yang lebih pekat dibandingkan dengan F2 (6\%) dan F1 (3\%).

Tabel 3. pH Sediaan Krim

\begin{tabular}{c|c}
\hline Formula & $\mathbf{p H}$ \\
\hline F0 & 8,1 \\
\hline F1 & 7,8 \\
\hline F2 & 7,2 \\
\hline F3 & 6,4 \\
\hline
\end{tabular}

Dari Tabel 3 di atas dapat diketahui bahwa formula krim yang memiliki basis yang sama dengan konsentrasi zat aktif yang berbeda, memiliki $\mathrm{pH}$ yang berbeda-beda pula. Dengan demikian, $\mathrm{pH}$ sediaan dipengaruhi oleh jumlah ekstrak yang digunakan. Semakin banyak jumlah ekstrak yang digunakan maka semakin rendah nilai $\mathrm{pH}$ sediaan. Hal ini disebabkan ekstrak biji kakao memiliki pH asam. Hal ini terbukti pada formula 3 memiliki $\mathrm{pH}$ lebih kecil dari formula lain sehingga hanya formula 3 yang memenuhi persyaratan $\mathrm{pH}$ kulit yaitu berkisar antara 4,5 - 6,5 akan tetapi secara keseluruhan sediaan krim tetap memiliki $\mathrm{pH}$ yang memenuhi standart SNI yaitu berkisar antara 4,5-8 [9]

Tabel 4. Hasil Uji Viskositas

\begin{tabular}{c|c}
\hline Formula & Viskositas \\
\hline F0 & $5261 \mathrm{cps}$ \\
\hline F1 & $4517 \mathrm{cps}$ \\
\hline F2 & $3603 \mathrm{cps}$ \\
\hline F3 & $2320 \mathrm{cps}$ \\
\hline
\end{tabular}

Semakin sedikit ekstrak dari sediaan krim maka semakin tinggi viskositasnya, sehingga sediaan tersebut akan semakin stabil karena pergerakan partikel cenderung sulit dengan semakin kentalnya suatu sediaan. Namun, kecepatan sediaan untuk mengalir lambat. Hal ini terlihat dari formula 1 yang memiliki nilai viskositas paling tinggi diantara formula 2 dan formula 3. Viskositas sediaan juga dipengaruhi oleh jumlah ekstrak yang digunakan. Semakin banyak jumlah ekstrak yang digunakan padasediaan maka viskositas akan semakin kecil. Hal ini terlihat pada F3 yang memiliki nilai viskositas paling kecil daripada F2 dan F1. Namun demikian, dari ketiga formula sediaan krim tetap memiliki nilai viskositas yang memenuhi standart SNI yaitu berkisar antara 2000-50.000 Cps [9].

Tabel 5. Hasil Uji Daya Sebar Krim

\begin{tabular}{c|c}
\hline Formula & Daya Sebar \\
\hline F0 & $5,47 \mathrm{~cm}$ \\
\hline F1 & $6,02 \mathrm{~cm}$ \\
\hline F2 & $6,54 \mathrm{~cm}$ \\
\hline F3 & $6,95 \mathrm{~cm}$ \\
\hline
\end{tabular}

Hasil evaluasi Tabel 5 menunjukkan bahwa ketiga formulasi memenuhi syarat daya sebar yang baik yaitu berkisar antara 5-7 cm. Nilai daya sebar sediaan berbanding terbalik dengan nilai viskosistas sediaan. Semakin besar daya sebar yang diberikan maka kemampuan zat aktif untuk menyebar pada kulit semakin luas. Hal ini terlihat pada formula 3 yang memiliki daya sebar paling baik dan mudah untuk diaplikasikan pada kulit [9]. 
Tabel 6. Hasil Uji Daya Lekat Krim

\begin{tabular}{c|c}
\hline Formula & DayaLekat \\
\hline F0 & 5,3 detik \\
\hline F1 & 4,6 detik \\
\hline F2 & 4,5 detik \\
\hline F3 & 4,2 detik \\
\hline
\end{tabular}

Hasil evaluasi Tabel 6 menunjukkan ketiga sediaan krim ekstrak biji kakao telah memenuhi syarat daya lekat yang baik. Pada formula 3 memiliki daya lekat paling rendah yaitu 4,2 detik dan daya lekat paling tinggi terdapat pada formula 1 yaitu 4,6 detik. Hasil pengujian daya lekat menunjukkan bahwa konsentrasi ekstrak mempengaruhi hasil daya lekat. Semakin tinggi konsentrasi ekstrak biji kakao dalam krim maka akan semakin kecil daya lekat yang diperoleh. Daya lekat yang semakin lama melekat pada kulit maka semakin baik karena zat aktif yang dilepaskan pada basis krimakan semakin banyak diabsorbsi [10].

Tabel 7. Hasil Uji Cycling Test

\begin{tabular}{c|c}
\hline Formula & Cycling test \\
\hline F0 & $\begin{array}{c}\text { Tidak terjadi } \\
\text { pemisahan }\end{array}$ \\
\hline F1 & $\begin{array}{c}\text { Tidak terjadi } \\
\text { pemisahan }\end{array}$ \\
\hline F2 & $\begin{array}{c}\text { Tidak terjadi } \\
\text { pemisahan }\end{array}$ \\
\hline F3 & $\begin{array}{c}\text { Tidak terjadi } \\
\text { pemisahan }\end{array}$ \\
\hline
\end{tabular}

Dari hasil uji cycling test pada ketiga formula ekstrak menunjukkan hasil yang baik dan stabil karena tidak adanya pemisahan fase antara ekstrak dengan basis dan juga tidak adanya pemisahan antara fase air dengan fase minyak.
Uji Stabilitas Sediaan Krim Ekstrak Biji Kakao

Tabel 8. Organoleptis Sediaan Pada Suhu $4^{\circ} \mathrm{C} \pm 2^{\circ} \mathrm{C}$

\begin{tabular}{l|l|l|l|l}
\hline Formula & M1 & M2 & M3 & M4 \\
\hline F0 & Stabil & Stabil & Stabil & Stabil \\
\hline F1 & Stabil & Stabil & Stabil & Stabil \\
\hline F2 & Stabil & Stabil & Stabil & Stabil \\
\hline F3 & Stabil & Stabil & Stabil & Stabil \\
\hline
\end{tabular}

Tabel 9. Organoleptis Sediaan Pada Suhu $28^{\circ} \mathrm{C} \pm 2^{\circ} \mathrm{C}$

\begin{tabular}{l|l|l|l|l}
\hline Formula & M1 & M2 & M3 & M4 \\
\hline F0 & Stabil & Stabil & Stabil & Stabil \\
\hline F1 & Stabil & Stabil & Stabil & Stabil \\
\hline F2 & Stabil & Stabil & Stabil & Stabil \\
\hline F3 & Stabil & Stabil & Stabil & Stabil \\
\hline
\end{tabular}

Tabel 10. Organoleptis Sediaan Pada Suhu $40^{\circ} \mathrm{C} \pm 2^{\circ} \mathrm{C}$

\begin{tabular}{c|c|c|c|c}
\hline Formula & M1 & M2 & M3 & M4 \\
\hline F0 & Stabil & Stabil & Stabil & Stabil \\
\hline F1 & Stabil & Stabil & Stabil & Stabil \\
\hline F2 & Stabil & Stabil & Stabil & Stabil \\
\hline F3 & Stabil & Stabil & Stabil & Stabil \\
\hline
\end{tabular}

Dari Tabel 8-10 dapat terlihat bahwa dengan suhu berbeda tidak ada perubahan dari warna, bentuk dan aroma setiap minggunya pada semua formula. Secara keseluruhan dapat disimpulkan bahwa penyimpanan sediaan krim pada suhu berbeda baik suhu $4^{\circ} \mathrm{C} \pm 2^{\circ} \mathrm{C}, 28^{\circ} \mathrm{C} \pm 2^{\circ} \mathrm{C}$ dan $40^{\circ} \mathrm{C} \pm 2^{\circ} \mathrm{C}$ tidak mempengaruhi organoleptis sediaan krim, atau organoleptis sediaan krim baik formula 0 , 1, 2 dan 3 stabil terhadap uji pada penyimpanan suhu $4^{\circ} \mathrm{C} \pm 2^{\circ} \mathrm{C}$, $28^{\circ} \mathrm{C} \pm 2^{\circ} \mathrm{C}$ dan $40^{\circ} \mathrm{C} \pm 2^{\circ} \mathrm{C}$. 


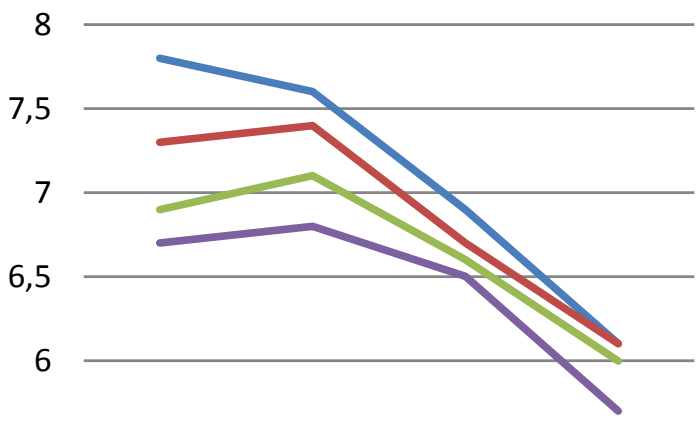

5,5

5

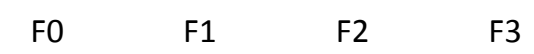

Minggu ke-1 Minggu ke-2

Minggu ke-3 —Minggu ke-4

Gambar 2. pH stabilitas pada suhu $4^{\circ} \mathrm{C} \pm 2^{\circ} \mathrm{C}$.

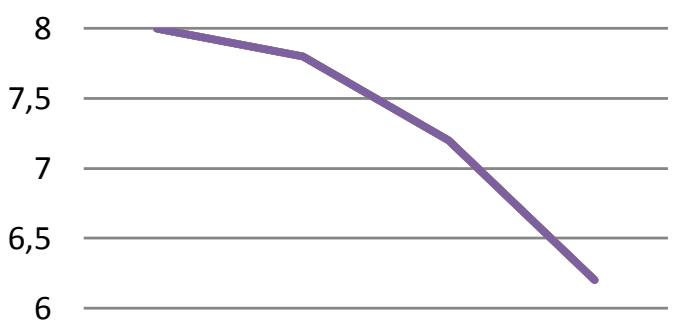

5,5

5
F0
F1
F2
F3

Minggu ke-1 Minggu ke-2

Minggu ke-3 $\longrightarrow$ Minggu ke-4

Gambar 3. $\mathrm{pH}$ stabilitas pada suhu $28^{\circ} \mathrm{C} \pm 2^{\circ} \mathrm{C}$

\section{8}

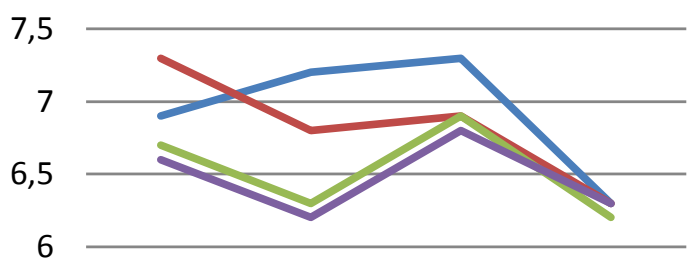

5,5

5

$\begin{array}{llll}\text { F0 } & \text { F1 } & \text { F2 } & \text { F3 }\end{array}$

Minggu ke-1 Minggu ke-2

Minggu ke-3 Minggu ke-4

Gambar 4. $\mathrm{pH}$ stabilitas pada suhu $40^{\circ} \mathrm{C} \pm 2^{\circ} \mathrm{C}$

Hasil pengukuran stabilitas $\mathrm{pH}$ sediaan krim di atas menunjukkan pada formula FO, F1, F2 dan F3 yang disimpan pada suhu rendah $\left(4^{\circ} \mathrm{C}\right)$, suhu sedang $\left(27-30^{\circ} \mathrm{C}\right)$ dan suhu tinggi $\left(40^{\circ} \mathrm{C}\right)$ mengalami sedikit penurunan $\mathrm{pH}$. Pada $\mathrm{F} 3$ mengalami perubahan nilai ph pada setiap suhu dan tetap memenuhi persyaratan ph kulit yaitu $4,5-6,5[7]$.

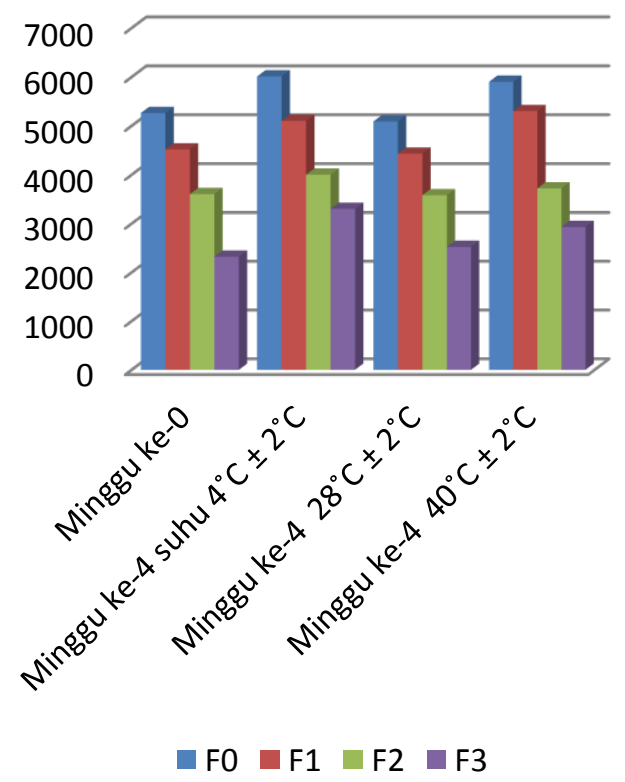

Gambar 5. Viskositas stabilitas sediaan krim 
Berdasarkan Gambar 4.5 hasil pengukuran viskositas pada keempat formula menunjukkan pada F1 memiliki viskositas paling tinggi.Hal ini terlihat pada F1 memiliki nilai viskositas lebih besar dibanding F2 dan F3.Semakin banyak jumlah ekstrak yang digunakan pada sediaan maka viskositas akan semakin kecil. Pada suhu $4^{\circ} \mathrm{C} \pm 2^{\circ} \mathrm{C}, 28^{\circ} \mathrm{C} \pm 2^{\circ} \mathrm{C}$ dan $40^{\circ} \mathrm{C} \pm 2^{\circ} \mathrm{C}$ keempat formula memiliki nilai viskositas tertinggi pada suhu $4^{\circ} \mathrm{C} \pm 2^{\circ} \mathrm{C}$ dan nilai viskositas terendah pada suhu $40^{\circ} \mathrm{C} \pm 2^{\circ} \mathrm{C}$ Viskositas berbanding terbalik dengan suhu, jika suhu naik maka viskositas akan turun dan begitu sebaliknya. Hal ini disebabkan karena adanya gerakan partikel-partikel cairan yang semakin cepat apabila suhu ditingkatkan dan menurun kekentalannya.

\section{Uji Daya Antibakteri}

Tabel 11. Hasil Uji Daya Antibakteri

\begin{tabular}{c|c}
\hline Formula & $\begin{array}{c}\text { Diameter Zona } \\
\text { Hambat (mm) }\end{array}$ \\
\hline F0 & 0 \\
\hline F1 & 7,61 \\
\hline F2 & 8,47 \\
\hline F3 & 9,92 \\
\hline F4 & 13,2 \\
\hline $\begin{array}{c}\text { Vitacid krim } \\
0.05 \%\end{array}$ & 13,2 \\
\hline
\end{tabular}

Hasil penelitian menunjukkan adanya daya hambat dari ekstrak biji kakao terhadap pertumbuhan bakteri Propionibacterium acne setelah proses inkubasi dengan suhu $37^{\circ} \mathrm{C}$ pada inkubator selama 24 jam. Inkubasi dilakukan dengan tujuan untuk mengondisikan lingkungan pada suhu optimum perkembangan bakteri sehingga dapat diketahui bahwa bakteri berkembang biak. Formula 3 memiliki diameter zona hambat yang paling besar dibanding yang lain yaitu $9,92 \mathrm{~mm}$. Luas zona hambat pada sediaan krim dengan pemberian konsentrasi ekstrak biji kakao yang berbeda termasuk dalam kategori daya hambat cukup dengan rata-rata diameter $5-10 \mathrm{~mm}$. Sebelumnya telah dilakukan pengujian ekstrak biji kakao terhadap P.acne dengan luas zona hambat 10,70 $\mathrm{mm}(3 \%), 12,30 \mathrm{~mm}$ (6\%), dan 13,90mm (12\%). Sehingga dapat disimpulkan bahwa luas zona hambat ekstrak lebih besar dibanding saat dibuat sediaan.

Tabel 12. Perbandingan Luas Zona Hambat Sediaan Krim dengan Pengawet dan Tidak menggunakan Pengawet

\begin{tabular}{l|l|l|l}
\hline $\begin{array}{l}\text { Krim } \\
\text { dengan } \\
\text { pengawet }\end{array}$ & $\begin{array}{l}\text { Diameter } \\
\text { zona } \\
\text { hambat } \\
\text { (mm) }\end{array}$ & $\begin{array}{l}\text { Krim tanpa } \\
\text { pengawet }\end{array}$ & $\begin{array}{l}\text { Diameter } \\
\text { zona } \\
\text { hambat } \\
\text { (mm) }\end{array}$ \\
\hline F0 & 0 & F0 & 0 \\
\hline F1 & 7,61 & F1 & 7,12 \\
\hline F2 & 8,47 & F2 & 8,09 \\
\hline F3 & 9,92 & F3 & 8,96 \\
\hline
\end{tabular}

Berdasarkan dari Tabel 4.7 dapat disimpulkan bahwa ada perbedaan antara sediaan krim dengan penambahan metil paraben dan tanpa penambahan metil paraben. Metil paraben banyak digunakan sebagai pengawet dan antimikroba dalam kosmetik, produk makanan dan formulasi farmasi dan digunakan baik sendiri atau dalam kombinasi dengan paraben lain atau dengan antimikroba lain. Pada sediaan krim dengan pengawet memiliki luas zona hambat lebih besar dibanding dengan krim tanpa pengawet. Hal ini membuktikan bahwa penambahan pengawet mempengaruhi luas zona hambat terhadap bakteri P.acne. Metil paraben efektif dalam menghambat bakteri pada kisaran $\mathrm{pH} 3-8$ dan memiliki aktivitas spektrum pada bakteri gram positif [11].

\section{KESIMPULAN DAN SARAN}

\section{Kesimpulan}

Berdasarkan penelitian formulasi sediaan krim ekstrak biji kakao ( $T$. cacao) dapat disimpulkan :

1. Ekstrak biji kakao dapat diformulasikan dalam sediaan krim dengan memiliki 
sifat fisik sediaan krim memenuhi standar SNI.

2. Sediaan krim ekstrak biji kakao ( $T$. cacao) memiliki aktivitas antibakteri terhadap P.acne.

\section{Saran}

Berdasarkan penelitian yang telah dilakukan disarankan untuk penelitian selanjutnya bahwa:

1.Perlu dilakukan penelitian lebih lanjut untuk menguji efektivitas ekstrak biji kakao dalam bentuk sediaan krim terhadap bakteri penyebab infeksi jerawat lainnya.

2. Perlu dilakukan penelitian lebih lanjut mengenai penggunaan minyak biji kakao dalam pembuatan sediaan krim dan aktifitas antibakterinya.

\section{Ucapan Terima Kasih}

Terimakasih Kepala dan Staf Universitas Tulang Bawang Lampung yang telah membantu dalam penelitian ini.

\section{DAFTAR PUSTAKA}

[1] Wulandari, P.,Suswati, E, Misnawi, \& Rianul A. Efek Antibakteri Ekstrak Etanol Biji Kakao Terhadap Pertumbuhan Shigella Dysentriae Secara In Vitro. J Med Planta. 2012;1.

[2] Djajadisastra. Formulasi gel topikaldari ekstrak nerii folium dalam sediaan anti jerawat. Farm Indones. 2009;4:210-6.

[3] Brown SK and Shalita AR. Acne vulgaris. Lancet J. 1998;

[4] MuhammadM RT. No More Antibiotyc For Acne.Skin Therapy Letter. 2013. 18:1-4.

[5] N.A Ariska. Efek Ekstrak Etanol Biji Kakao(Theobromacacao)sebagai
Antibakteri

terhadap Propionibacterium acnes Secara In Vitro. 2015;

[6] Voight Rudolf. Buku Pelajaran Teknologi Farmasi. yogyakarta: Gadjah Mada University Press; 1994.

[7] Martin A, Swarbick CA. Farmasi Fisik. Jakarta: Universitas Indonesia; 1993. 1096 p.

[8] Departemen Kesehatan RI. Pedoman Pengujian dan Pengembangan Fitofarmaka, Penapisan Farmakologi, Pengujian Fitokimia dan Pengujian Klinik. Jakarta; 1993.

[9] Badan standardisasi nasional. SNI 16-4399-1996. Jakarta; 1996. 1 p.

[10] Voigt. Buku Pelajaran Teknologi Farmasi. Yogyakarta: Universitas Gajah Mada; 1995. 381-382 p.

[11] Rowe,R.C., Sheskey, P.J., and Owen S. Handbook of Pharmaceutical Excipients. 5rd ed. American Pharmaceutical Association: Pharmaceutical Press; 2005. 346, 466 dan624 p. 